\title{
Current Knowledge of Coffee Wilt Disease, a Major Constraint to Coffee Production in Africa
}

\author{
Mike A. Rutherford
}

CABI Bioscience, UK Centre, Bakeham Lane, Egham, Surrey TW20 9TY, UK.

Accepted for publication 10 January 2006.

\begin{abstract}
Rutherford, M. A. 2006. Current knowledge of coffee wilt disease, a major constraint to coffee production in Africa. Phytopathology 96:663-666.

Coffee is vital to the economy of East and Central Africa, providing a major source of foreign exchange earnings and, as a cash crop, supporting the livelihoods of millions involved in cultivation, processing, marketing, and export. Coffee wilt disease (CWD), attributed to Gibberella xylarioides (Fusarium xylarioides), has caused losses to coffee production in Africa since 1927 but has been largely contained through the use of host resistance and in some instances wide-scale sanitation practices. A reemergence of CWD on Coffea canephora (Robusta coffee) in Uganda,

Democratic Republic of Congo, and Tanzania has already led to heavy losses and threatens future production in these countries and elsewhere in the region. The relevance of CWD is all the more pertinent given the impact of a considerable fall in world coffee prices over the last decade. Recent research has clarified the extent of the problem in the region and revealed a low level of diversity within the pathogen, suggesting that two genetically and biologically distinct forms are responsible for current problems. These findings and related research and development initiatives undertaken under the auspices of the Regional Coffee Wilt Programme are of fundamental importance in providing an urgently needed solution to this devastating disease.
\end{abstract}

As a commodity, coffee represents $1 \%$ of the total value of global imports and exports. More than 60 million people depend on production and export of coffee for income in 51 countries throughout the world. Developing country earnings alone amount to more than US $\$ 10$ billion per year. Production of the crop is currently based on two species, Coffea arabica L. (Arabica coffee) and C. canephora Pierre ex. A. Froehner (Robusta coffee), which represent approximately 67 and 33\% of global production, respectively. A number of African countries are heavily dependant on coffee as a source of foreign exchange earnings and government income through taxation. Coffee also provides employment through cultivation, processing, marketing, transportation, and exportation of the crop. It constitutes a cash crop of fundamental importance to the livelihoods of millions of resource poor farmers across the continent, many relying on coffee as their only source of income. Until the mid-1900s, coffee production in Africa was based largely on C. excelsa A. Chev. and C. arabica. However, C. excelsa has since been replaced by $C$. canephora, primarily due to the impact of coffee wilt disease (CWD), a vascular wilt disease also referred to as Fusarium wilt or tracheomycosis of coffee. CWD is currently having a devastating effect on coffee production in parts of eastern and central Africa and continues to spread at an alarming rate. Unlike many other diseases of coffee, CWD will rapidly kill an infected mature tree, often within as little as 6 months following appearance of the first external symptoms, and thus ultimately result in total yield loss. Coffee quality may also be affected through, for example, premature ripening of the berries.

Corresponding author: M. A. Rutherford; E-mail address: m.rutherford@cabi.org

* The $\boldsymbol{e}$-Xtra logo stands for "electronic extra" and indicates that the online version contains supplemental material not included in the print edition. Figure 1 appears in color online.

DOI: 10.1094/PHYTO-96-0663

(C) 2006 The American Phytopathological Society

\section{COFFEE WILT DISEASE}

The pathogen. CWD is attributed to the fungus Fusarium xylarioides (anamorph) Steyaert, described by Steyaert (32) as a new species causing wilt of coffee (C. excelsa). The teleomorph of the fungus was subsequently referred to as Gibberella xylarioides Heim \& Saccas, based on the morphology of the asci and ascospores (18).

Morphology of the fungus. As with many fusaria, colony morphology may vary depending on culture media and environmental conditions. The morphology described here is principally based on that of Booth and Waterston (3). On potato sucrose agar ( $\mathrm{pH}$ 6.5), a medium routinely used for identification of fusaria, cultures of the anamorph are initially pale beige with sparse white mycelium. A purple discoloration later develops, accompanied by dark bluish black, discrete stromata, some of which represent ascomatal initials. Micro- and macroconidia are produced in slimy masses on short conidiogenous cells on the vegetative mycelium. Microconidia, generally abundant, are unicellular, allantoid, curved and 5 to $10 \times 2.5$ to $3 \mu \mathrm{m}$. Macroconidia are less abundant, fusoid, falcate, 2 to 3 septate and 20 to $25 \times 4$ to $5 \mu \mathrm{m}$. Chlamydospores, oval to globose, smooth or roughened and 10 to $15 \times 8$ to $10 \mu \mathrm{m}$, may not be abundant if produced at all (33). Perithecia, which are produced on coffee plants under natural conditions $(16,33)$, are violaceous and embedded, single or in groups, in dark purple stromata. They are globose with a flattened base, 200 to $400 \times 180$ to $300 \mu \mathrm{m}$. Asci are cylindrical and thin-walled, shortly pedicellate and measuring 90 to $110 \times 7$ to $9.5 \mu \mathrm{m}$. Asci contain eight monostichous ascospores, which are hyaline to straw-colored, fusoid, 1 to 3 septate, finely roughened and 12 to $14.5 \times 4.5$ to $6 \mu \mathrm{m}$ ) $(3,32)$. The existence of sex-linked male and female forms of F. xylarioides distinguishable on morphological characters and reported by Booth (2) has been in question (described below).

Symptoms. External. Initially chlorosis, wilting, and drying of the leaves progressing to a gradual and often unilateral dieback 
and defoliation that ultimately extends to the entire tree and results in death $(33,35)$. Berries of affected trees turn red and appear to ripen prematurely (10). Dark brown-black necrosis of younger branches may be pronounced and laterally restricted, while a similar necrosis may also be apparent along leaf veins (Fig. 1). Care should be taken in diagnosing early external symptoms, especially chlorosis and wilting of leaves, as these may be due to other fusaria of coffee, namely $F$. solani (dry root rot), F. stilboides ([Storey's] bark disease), and $F$. oxysporum, or a physiological disorder, overbearing dieback. Spiral cracks may form along the bark and may bear perithecia of the fungus under suitable environmental conditions (28). Internal. CWD is readily distinguished by a necrosis in the tree that, unlike discoloration due to other fusaria, is characterized by blue-black staining of wood (vessels) immediately below the bark $(16,35)$. The discoloration is usually pronounced at the base of the tree, may extend from below soil level to the apex of the tree and spiral along stems and branches as it follows vascular tissues (Fig. 1).

Transmission. Considered to be a soil inhabiting fungus (20), the conidia may be spread by water (rainfall), wind, and human activity and penetrate the host through wounds caused by weeding and pruning. Wood pieces used for vegetative propagation may be an important source of spread, while coffee seeds (berries) have been shown not to transmit the disease $(15,19,29,33)$.

Management. Prospects for effectively managing CWD in the future are based largely on host resistance, and current research and development efforts are focused in this direction. Considered to be horizontal in nature, resistance does present a long-term and
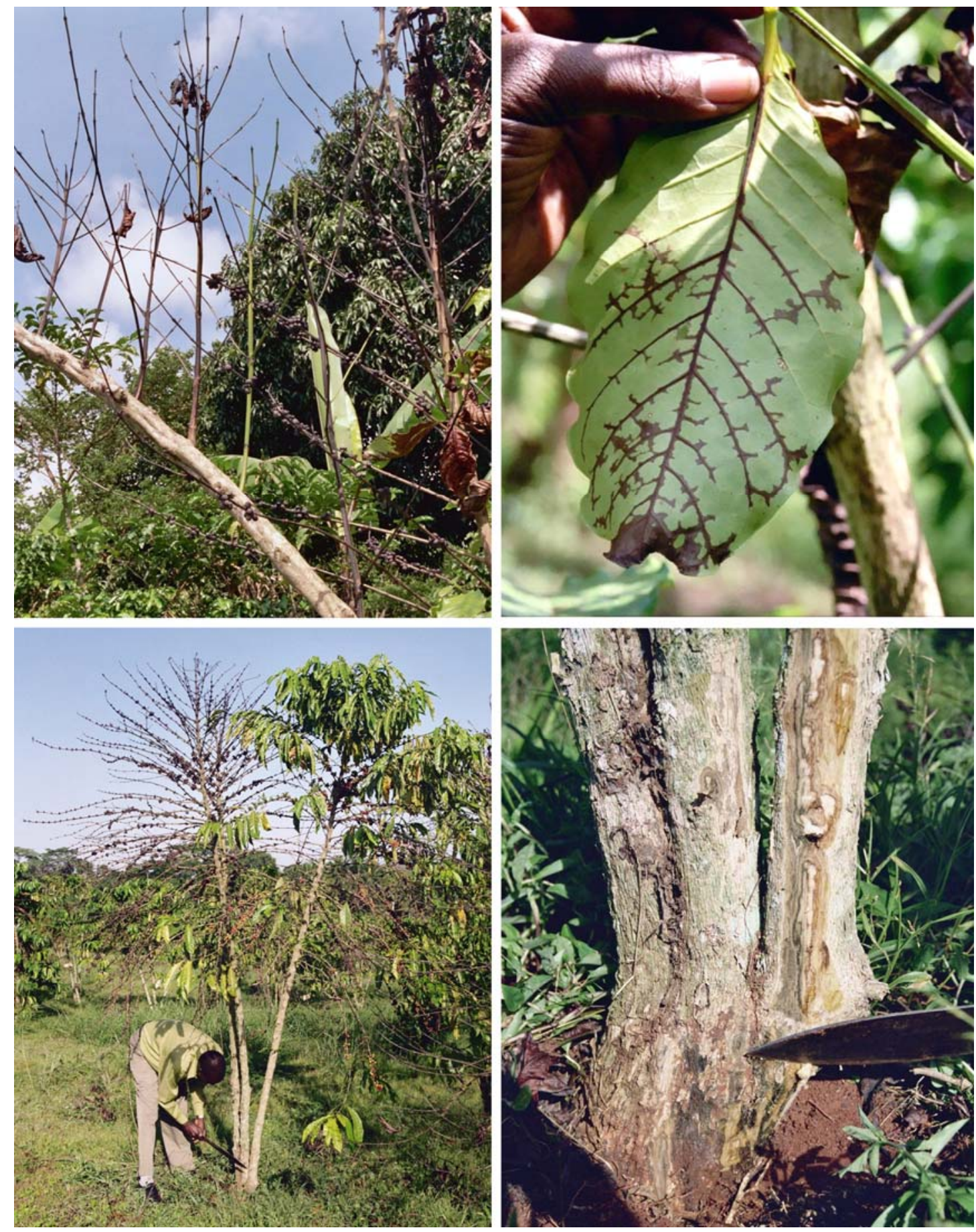

Fig. 1. Symptoms of coffee wilt disease on coffee (Coffea canephora) in Uganda. Clockwise from top left: defoliation and dieback; necrosis of leaf veins; blueblack staining of wood (vessels) beneath the bark; and lateral defoliation of coffee tree (note that berries remain intact). 
stable solution to the problem $(4,5,10,33)$. Resistance is being sought within cultivated $C$. canephora, C. arabica $\times C$. canephora ('Arabusta') hybrids, wild coffee, and coffee grown outside Africa (1; D. Bieysse, unpublished data; G. Oduor, unpublished data). In Uganda, a number of susceptible but carefully selected indigenous clonal lines of $C$. canephora have been multiplied and provided to farmers as clean planting material. When these are interplanted in rows, each row comprising a different clone, overall crop losses due to CWD are reduced and yields increased, possibly due to spread of the pathogen across the rows being restricted (G. Hakiza, personal communication). Recommended phytosanitary practices, including disinfection of tools, utilizing clean planting material and uprooting and burning affected trees, are of some benefit but their adoption is constrained by on-farm resources. Chemical pesticides have also been suggested as a control measure $(11,20,29)$ but their effect is likely to be limited due to the vascular nature of the pathogen.

History, current distribution, and impact. CWD has been recognized for more than 70 years. It was first reported on C. excelsa in Central African Republic (CAR) in 1927 (6) and has since developed on $C$. canephora in Côte d'Ivoire during the 1940s and 1950s and the Democratic Republic of Congo (DRC, formerly Zaire) from about $1949(5,10,17,28,32)$. In each case, major losses were incurred, with more than $50 \%$ of the coffee producing areas being destroyed in Cote d'Ivoire and DRC. Of significance, some $C$. excelsa and $C$. canephora lines found to be susceptible in CAR and DRC, respectively, exhibited resistance to the disease in Côte d'Ivoire, leading to speculation that climatic factors may have been responsible or that variability existed within the pathogen $(10,24)$. In 1957, symptoms similar to those of CWD were documented for the first time in Ethiopia, on the widely cultivated $C$. arabica $(21,22,31)$. Over a period of less than 30 years, CWD had effectively destroyed millions of C. excelsa, $C$. canephora, and $C$. arabica trees to become the most serious disease of coffee on the African continent. From the late 1950 s, a program of systematic uprooting and destruction of affected coffee plants over vast areas, relocation of coffee production to new locations, and planting with resistant $C$. canephora germ plasm proved highly successful in eradicating the disease from Cote d'Ivoire and DRC (24,29). Although this resulted in CWD becoming considered economically as a minor disease on C. canephora, C. excelsa never recovered as a commercial crop. In Ethiopia, breeding programs were also initiated for $C$. arabica with some success, although pockets of the disease did remain $(27,33)$.

Symptoms of CWD were again observed in the 1970s and by 1992 the disease was causing widespread destruction on C. canephora in northeast DRC $(7,25)$. It was observed for the first time in neighboring Uganda in $1993(8,9)$ to become widespread $(23)$ and by 1996 had spread to Mukono district, where $40 \%$ of Uganda's C. canephora was grown. In Ethiopia, CWD was also on the increase to become endemic to all $C$. arabica producing areas and reached epidemic proportions in some, possibly due to intensification of cropping practice (27).

Surveys undertaken since 2001 have confirmed the presence of CWD on C. canephora in DRC, Uganda, and Tanzania. C. arabica, also cultivated in these countries, was found to be free of the disease even where grown alongside affected $C$. canephora plants (G. Oduor, unpublished data). In DRC, two of the six coffee producing provinces, to the northeast of the country and forming the major production area, were affected with more than $90 \%$ of farms experiencing difficulties. A similar situation was found in Uganda, where all 27 C. canephora growing districts were affected and yield losses averaged $70 \%$. In Tanzania, CWD was confined to Kagera district, to the north-west of the country and bordering Uganda. In Ethiopia, $28 \%$ of C. arabica producing farms were affected, including those in the major coffee areas. C. canephora, grown in small quantities at research stations and on some planta- tions, was free of the disease. Rwanda, lying between the affected areas of DRC, Uganda, and Tanzania, was disease free although here cultivation is based predominantly on C. arabica $(1,13,15$, 16; G. Oduor, unpublished data).

Pathogen diversity and the role of the sexual cycle. Molecular studies, including analyses of amplified fragment length polymorphisms, enzymatic digestion of the ribosomal DNA intergenic spacer region, generation of mitochondrial DNA restriction fragment length polymorphisms, and microsatellite-based polymerase chain reaction analyses, have revealed very little genetic diversity within the coffee wilt pathogen (D. Bieysse, unpublished data; M. Rutherford, unpublished data). However, the studies do suggest that two, possibly clonal, populations are responsible for current CWD outbreaks in Africa, one comprising isolates obtained from affected C. arabica in Ethiopia (variant 'A'), the other isolates from affected $C$. canephora in DRC, Uganda, and Tanzania (variant ' $C$ '). All of the isolates examined exhibited morphological characters in line with those of $F$. xylarioides as described by Steyaert (32) and of the female form of the species as described by Booth (2). Recent pathogenicity testing under screen house and glasshouse conditions in Africa and Europe has confirmed that host specificity is operating within the pathogen. This relates to genetic diversity in that isolates of variant ' $\mathrm{A}$ ' are pathogenic to $C$. arabica but not to C. canephora, the converse applying to isolates of variant ' $\mathrm{C}$ '. Variation in isolate aggressiveness and host response to a specific isolate has been observed for each population. Investigation of a small number of isolates obtained from C. excelsa trees affected by CWD in CAR, Côte d'Ivoire, and Guinea in the 1950s and 1960s (i.e., during the earlier outbreak) has shown these to be genetically dissimilar to variant ' $A$ ' and variant ' $C$ '. Furthermore, one of the isolates from $C$. excelsa (the only one tested to date) not only induced CWD symptoms on $C$. excelsa but, unlike variants 'A' and 'C', was also found to be cross pathogenic to $C$. arabica and to C. canephora (14; D. Bieysse, unpublished data).

As a species, $F$. xylarioides has been classified as a member of Fusarium Section Lateritium. However, recent phylogenetic studies of $F$. xylarioides isolates again fitting the original description of the species (32) and of the female form (2), including a number obtained from CWD affected coffee trees in Uganda, have shown these to belong to the African clade of the G. fujikuroi species complex, a clade replacing Fusarium Section Liseola $(12,26)$. Two distinct tef alleles were also observed, one within isolates from Eastern Africa, the other isolates from Western Africa. Isolates previously identified as $F$. lateritium, $F$. stilboides, and the male form of $F$. xylarioides (2) did show a phylogenetic connection to the clade Lateritium. Their role in the development of CWD, if any, remains unclear. These findings coupled with earlier reports (14, 30,34) suggest that Booth's description of sex-linked male and female forms of $F$. xylarioides distinguishable by morphological characters were perhaps misplaced. Very recent but preliminary studies do nevertheless suggest that the pathogen is heterothallic, as shown by the production of fertile progeny (denoted by asci and ascospore formation) when two compatible isolates are paired in vitro (D. Bieysse, unpublished data; P. Lepoint, unpublished data). However, while sexual compatibility appears to exist within the variant ' $A$ ' population and within the variant ' $C$ ' population, to date compatibility has not been observed between the two populations. This finding may help to explain the limited genetic variability observed within the pathogen, and also why perithecial formation is so readily observed under natural field conditions but not following inoculation of coffee seedlings with monosporic cultures of the pathogen $(16,33)$.

\section{CONCLUSION}

The widespread destruction of $C$. canephora observed in east and central Africa confirms that CWD has re-emerged as a major constraint to coffee production in the region. Its development also 
suggests that it originated, and subsequently spread from, DRC to Uganda and northwest Tanzania. Studies of pathogen diversity suggest that a genetically and biologically distinct variant of the pathogen is responsible but how, and from where, this variant arose in relation to previous outbreaks in west and central Africa remains unclear. Are current CWD problems due to a pre-existing strain of $F$. xylarioides that has spread as cultivation of $C$. canephora lines, previously considered resistant, has expanded? Or has a new variant evolved from an earlier and perhaps more diverse population, perhaps as a result of intensification of C. canephora and hence selection pressure? In Ethiopia, the CWD problem on $C$. arabica is deepening and there is an urgent need to determine whether this is due to a change in the pathogen or linked to cropping practice.

Observations of a narrow genetic base, host specificity, and apparent limitations to sexual recombination within the pathogen are potentially a positive development in terms of managing the disease through host resistance and restricting the introduction and spread of virulent forms to new areas. Our understanding of CWD has been somewhat limited to date. Generating new knowledge such as that reported here is a fundamental need and will be of major benefit in preventing further disease spread and ultimately eradicating CWD as a constraint to coffee farmers in Africa.

\section{ACKNOWLEDGMENTS}

This paper is dedicated to the memory of our colleague Dr. David Brayford, a mycologist and Fusarium taxonomist who investigated coffee wilt disease at CABI Bioscience in the 1990s. David sadly passed away on 22 July 2005.

We thank those who provided information required for the preparation of this manuscript, particularly colleagues at Coffee Research Institute (CORI, Uganda), Ethiopian Agricultural Research Organisation (EARO), Tanzania Coffee Research Institute (TaCRI, Tanzania), Universite Catholique de Louvain (UCL, Belgium), and Centre de Coopération Internationale en Recherche Agronomique pour le Développement (CIRAD, France). Gratitude is also extended to colleagues at CABI Bioscience (UK and Kenya), and other researchers, extension personnel and farmers who are working together to help combat coffee wilt disease in Africa. There are too many to be named individually here but their inputs, large or small, are greatly appreciated.

\section{LITERATURE CITED}

1. Birikunzira, J. B., and Hakiza, G. J. 1997. The status of coffee wilt disease (tracheomycosis) and strategies for its control in Uganda. Pages 766-770 in: Dix-Septième Colloque Scientifique International sur le Café, Nairobi, Kenya.

2. Booth, C. 1971. The Genus Fusarium. Commonwealth Mycological Institute, Kew.

3. Booth, C., and Waterston, W. M. 1964. CMI Descriptions of Plant Pathogenic Fungi and Bacteria No. 24. CAB International, Wallingford, UK.

4. Bouriquet, G. 1959. Plant diseases and pests in some African territories. FAO Plant Prot. Bull. 7:61-63.

5. Deassus, E. 1954. La trachéomycose du Caféier. Bull. Sci. Minist. Colon. Sect. Agron. Trop. 5:345-348.

6. Figueres, R. 1940. Sur une maladie très grave du caféier en Oubangui. Rapport. Ministère des Colonies, Paris, France.

7. Flood, J. 1996. A study of the tracheomycosis or vascular wilt disease of coffee in Zaire. Consultant's report submitted to International Coffee Organization, August 1996. CAB International, Wallingford, UK.

8. Flood, J., and Brayford, D. 1997. The re-emergence of Fusarium wilt of coffee in Africa. Proceedings of the International Scientific Colloquium on Coffee (ASIC) Conference. ASIC, Nairobi, Kenya.

9. Flood, J., and Brayford, D. 1998. Fusarium wilt of coffee in Africa. Proceedings of the 7th International Congress of Plant Pathology, Edinburgh.
10. Fraselle, J. 1950. Observations préliminaires sur une Trachéomycose de Coffea robusta. Bull. Agric. Congo Belge. XLI:361-372.

11. Gaudy, M. R. 1956. Contribution du techniques, scientifique ou développement de l'agriculture en Afrique Occidentale Francaise. J. West Afr. Sci. Assoc. 2:172-197.

12. Geiser, D. M., Lewis Ivey, M. L., Hakiza, G., Juba, J. H., and Miller, S. A. 2005. Gibberella xylarioides (anamorph: Fusarium xylarioides), a causative agent of coffee wilt disease in Africa, is a previously unrecognized member of the G. fujikuroi species complex. Mycologia 97:191-201.

13. Girma, A. 1997. Status and economic importance of Fusarium wilt disease of Arabica coffee in Ethiopia. Pages 53-61 in: Proceedings of the First Regional Workshop on Coffee Wilt Disease (Tracheomycosis). G. J. Hakiza, B. Birkunzira, and P. Musoli, eds. International Conference Centre, Kampala, Uganda.

14. Girma, A. S. 2004. Diversity in pathogenicity and genetics of Gibberella xylarioides (Fusarium xylarioides) populations and resistance of Coffea spp. in Ethiopia. Ph.D. diss. University of Bonn, Germany.

15. Girma, A., and Hindorf, H. 2001. Recent investigation on coffee tracheomycosis, Gibberella xylarioides (Fusarium xylarioides) on Arabica coffee in Ethiopia. Proceedings 19th International Scientific Colloquium on Coffee (ASIC). ASIC, Trieste, Italy.

16. Girma, A., Mengistu, H., and Hindorf, H. 2001. Incidence of tracheomycosis, Gibberella xylarioides (Fusarium xylarioides), on Arabica coffee in Ethiopia. Z. Pflanzenkrankh. Pflanzen. 108:136-142.

17. Guillemat, J. 1946. Quelques observations sur la trachéomycose du Coffea excelsa. Rev. Bot. Appl. Agric. Trop. 26:542-550.

18. Heim, R., and Saccas, A. 1950. La trachéomycose des Coffea et Robusta des plantations de L'Oubangui-Chari. Rev. Mycol. Supplément Colonial 15:97.

19. Holliday, P. 1980. Fungus Diseases of Tropical Crops. Cambridge University Press, UK.

20. Jacques-Felix, H. 1954. La carbunculariose. Bull. Sci. Minist. Colon. Sect. Agron. Trop. 5:296-344.

21. Kranz, J., and Mogk, M. 1973. Gibberella xylarioides Heim et Saccas on arabica coffee in Ethiopia. Phytopathol. Z. 78:365-366.

22. Lejeune, J. B. H. 1958. Rapport au Gouvernement imperial d'Ethiopie sur la production caféière. Rep. FAO. Vol. 797. FAO, Rome, Italy.

23. Lukwago, G., and Birikunzira, J. B. 1997. Coffee wilt disease (tracheomycosis) and its implication on Uganda's economy. Afr. Crop Sci. Conf. Proc. 3:969-974

24. Meiffren, M. 1961. Contribution aux recherches sur la trachéomycose du Caféier en Côte d'Ivoire. Café Cacao Thé 5:28-37.

25. Mfwidi-Nitu, P. 1994. The recrudescence of tracheomycosis (Gibberella xylarioides) of Robusta coffee in Zaire. Afr. Coffee Bull. 40:9-12.

26. O’Donnell, K., Cigelnik, E., and Nirenberg, H. I. 1998. Molecular systematics and phylogeography of the Gibberella fujikuroi species complex. Mycologia 90:465-493.

27. Pieters, R., and van der Graaff, N. A. 1980. Resistance to Gibberella xylarioides in Coffea arabica: Evaluation of screening methods and evidence for the horizontal nature of the resistance. Neth. J. Plant Pathol. $86: 37-43$.

28. Saccas, A. M. 1951. La Trachéomycose (Carbunculariose) des Coffea excelsa, neo-arnoldiana at robusta en Oubangui-Chari. Agron. Trop. 6:453-506

29. Saccas, A. M. 1956. Recherches expérimentales sur la trachéomycose des caféiers en Oubangui-Chari. Agron. Trop. 11:7-38.

30. Samuels, G. J., Nirenberg, H. I., and Seifert, K. A. 2001. Perithecial species of Fusarium. Pages 1-14 in: Fusarium. Paul E. Nelson Memorial Symposium. B. A. Summerell, J. F. Leslie, D. Backhouse, W. L. Bryden, and L. W. Burgess, eds. The American Phytopathological Society, St. Paul, MN.

31. Stewart, R. B. 1957. Pages 15-16 in: Some Diseases occurring in Kaffa Province, Ethiopia. Imperial Ethiopian College of Agriculture and Mechanical Arts, Alemaya, Ethiopia.

32. Steyaert, R. L. 1948. Contribution à l'étude des parasites des végétaux du Congo Belge. Bull. Soc. Roy. Bot. Belgique 80:11-58.

33. van der Graaff, N. A., and Pieters, R. 1978. Resistance levels in Coffea arabica to Gibberella xylarioides and distribution patterns of the disease. Neth. J. Plant Pathol. 84:117-120.

34. von Blittersdorff, R., and Kranz, J. 1976. Vergleichende Untersuchungen an Fusarium xylarioides Steyaert (Gibberella xylarioides Heim et Saccas), dem Erreger der tracheomykose des kaffees. Z. Pflanzenkrankh. Pflanzen. 83:529-544.

35. Wrigley, G. 1988. Coffee. Tropical Agriculture Series. Longman, London. 